\title{
Hiper IgE dengan Nekrolisis Epidermal Toksik
}

\author{
Adrian Ramdhany ${ }^{1}$, Raveinal ${ }^{2}$
}

\begin{abstract}
Abstrak
Hiper IgE (HIES) disebut juga sindroma Ayub adalah gangguan komplek imun primer yang ditandai dengan dermatitis atopik seperti dikulit yang berhubungan dengan peningkatan IgE serum yang sangat tinggi dan kerentanan terhadap infeksi bakteri dan jamur. Kelainan non imun yang terjadi termasuk tampilan wajah yang khas, fraktur setelah truma ringan, skoliosis, hiperextensive sendi, dan retensi gigi sulung. Penelitian terbaru menunjukkan bahwa mutasi dominan terjadi pada sinyal tranduser dan aktivator transkripsi 3 (STAT 3), sedangkan defisiensi gen tirosin kinase 2 (TYK2) menyebabkan HIES autosomal resesif terkait dengan virus dan infeksi mikrobakteri. Dalam kedua kondisi tersebut, sinyal transduksi untuk beberapa toksin, termasuk IL-6 dan IL-23 adalah cacat, sehingga fungsi TH17 terganggu. Temuan ini menunjukkan bahwa cacat dalam sinyal sitokin merupakan dasar molekuler untuk kelainan imunologi dan nonimunologi yang diamati pada HIES. Nekrolisis epidermal toksik ditemukan pertama kali pada tahun 1956, sebanyak 4 kasus oleh Alana Lyell, penyakit ini biasanya juga disebut sindrom Lyell. Lyell menggunakan istilah 'nekrolisis' dengan menggabungkan gejala klinis epidermolisis dengan gambaran histopatologi 'nekrosis'. Penyebab Nekrolisis Epidermal Toksik (NET) belum jelas, tetapi obat-obatan (sulfonamid dan butazones) dan spesies Staphylococcus merupakan penyebab utama. Akibatnya, istilah-istilah seperti 'staphylococcal-induced toxic epidermal necrolysis' dan 'drug-induced scalded skin syndrome' menang selama beberapa dekade, tetapi sekarang dipisahkan karena terapi dan prognosisnya berbeda. Oleh karena itu nekrolisis epidermal toksik atau NET merupakan penyakit erupsi kulit yang umumnya timbul akibat obat-obatan dengan lesi berupa bulla, dengan penampakan kulit seperti terbakar yang menyeluruh.
\end{abstract}

Kata kunci: sindrom hiper igE, nekrolisis epidermal toksik

\section{Abstract}

Hyper IgE (HIES) also called Job syndrome is a disorder of the primary immune complex characterized by atopic dermatitis such as skin which is associated with a very high increase in serum IgE and susceptibility to bacterial and fungal infections. Non-immune abnormalities that occur include a distinctive facial appearance, fractures after mild injury, scoliosis, hiperextensive joints, and retention of primary teeth. Recent studies have shown that dominant mutations occur in the transducer signal and activator of transcription 3 (STAT 3), whereas tyrosine kinase 2 gene deficiency (TYK2) causes autosomal recessive HIES associated with viruses and microbacterial infections. In both conditions, the transduction signal for some toxins, including IL-6 and IL-23, is defective, so the TH17 function is impaired. These findings suggest that defects in cytokine signals are the molecular basis for immunological and nonimmunological abnormalities observed in HIES. Toxic epidermal necrolysis was first discovered in 1956, as many as 4 cases by Alana Lyell, this disease is usually also called Lyell syndrome. Lyell uses the term 'necrolysis' by combining epidermolysis clinical symptoms with histopathological features of 'necrosis'. The cause of NET is not yet clear, but drugs (sulfonamides and butazones) and Staphylococcus species are the main causes. As a result, terms such as "staphylococcal-induced toxic epidermal necrolysis" and "drug-induced scalded skin syndrome" have won for decades, but are now separated because of different therapies and prognosis. Therefore, toxic epidermal necrolysis or NET is a skin eruption disease that generally results from drugs with bullae-shaped lesions, with a thorough burninglike skin appearance.

Keywords: hyper IgE, necrolysis epidermal toxic 
Affiliasi penulis: 1. Program Pendidikan Dokter Spesialis-1 IImu Penyakit Dalam FK Unand 2. Subbagian Alergi Imunologi Bagian IImu Penyakit Dalam FK Unand/RSUP M Djamil Padang

Korespondensi: pibipd@yahoo.com, Telp: 0751-37771

\section{PENDAHULUAN}

Hiper IgE (HIES) disebut juga sindroma Ayub adalah gangguan komplek imun primer yang ditandai dengan dermatitis atopik seperti dikulit yang berhubungan dengan peningkatan IgE serum yang sangat tinggi, dan kerentanan terhadap infeksi bakteri dan jamur. Kelainan non imun yang terjadi termasuk tampilan wajah yang khas, fraktur setelah truma ringan, skoliosis, hiperextensive sendi, dan retensi gigi sulung. Penelitian terbaru menunjukkan bahwa mutasi dominan terjadi pada sinyal tranduser dan aktivator transkripsi 3 (STAT 3), sedangkan defisiensi gen tirosin kinase 2 (TYK2) menyebabkan HIES autosomal resesif terkait dengan virus dan infeksi mikrobakteri. Dalam kedua kondisi tersebut, sinyal transduksi untuk beberapa toksin, termasuk IL-6 dan IL-23 adalah cacat, sehingga fungsi TH17 terganggu. Temuan ini menunjukkan bahwa cacat dalam sinyal sitokin merupakan dasar molekuler untuk kelainan imunologi dan nonimunologi yang diamati pada HIES. ${ }^{1,2,3,4}$

\section{Manifestasi Klinis}

HIES adalah penyakit multisistem dengan manifestasi klinis yang bervariasi. Individu yang terkena mungkin memiliki beberapa ciri-ciri dari HIES, tapi tidak semua gejala muncul, tergantung pada usia. Hampir semua pasien dengan HIES menderita infeksi Staphylococcus berulang, dimulai pada waktu bayi dan sering melibatkan kulit dan paru-paru. Berbeda dengan penyakit gralumatosis dimana infeksi Staphylococcus terjadi di berbagai organ, termasuk paru-paru, kelenjar getah bening, kulit, hati, saluran pencernaan, ginjal dan otak. Pasien dengan HIES dapat didiagnosis dengan skor yang diciptakan oleh Grimbacher. $5,6,7,8$

Staphylococcus aureus adalah bakteri yang paling sering terisolasi pada pasien HIES namun Sterptococcus pneumoniae, Haemophilus influenza, dan bakteri gram negatif juga ditemukan pada pasien HIES. Infeksi jamur, termasuk candidiasis mukokutan dan aspergillosis paru, juga sering ditemukan pada HIES. Dermatitis atopi biasanya dimulai selama periode neonatal, sebelum timbulnya dermatits atopik. Pasien dengan HIES menderita dermatitis atopi terkait dengan sangat tinggi tingkat $\lg E$ serum dan eosinofilia, tetapi biasanya bebas dari manifestasi alergi lainnya, seperti rhinitis,urtikaria, dan reaksi anafilaksis. Kelainan kraniofasial pada pasien HIES memiliki penampilan wajah yang khas yang berkembang pada masa anak-anak dan remaja, ditandai dengan asimetris, hidung lebar, dan mata cekung dengan dahi menonjol. Kulit wajah sering memiliki tekstur kasar, berpori. ${ }^{5,6}$

Kelainan muskulosketal berupa skoliosis, patah tulang pada trauma minimal, osteopenia, hiperextensibiltas dan penyakit sendi degeneratif. Skoliosis sering muncul pada masa remaja. Fraktur trauma minimal terjadi pada $50 \%$ pasien dengan HIES dimana osteopenia dan osteiporosis juga terjadi. Osteoklas dimediasi reabsorpsi tulang yang tidak normal pada HIES dan kemungkinan berhubungan dengan osteopenia dan patah tulang. Kelainan gigi pada HIES adalah gigi sulung yang sulit tanggal dan memerlukan ekstaksi pembedahan. Karakteristik variasi mukosa mulut, lidah, langit-langit mulut dan pipi termasuk lidah yang mungkin berhubungan dengan infeksi candida.5,6

Kelainan vaskuler yang terjadi pada HIES biasanya berupa aneurisma arteri koroner mengakibatkan infark miokard, aneurisma bilateral karotis, mikosis arteri serebral, dan kelainan pembuluh darah kecil. Keganasan pada HIES dikaitkan dengan tingkat kejadian limfoma non hodgkin yang sebagian besar berasal dari sel B. ${ }^{5,6}$

Nekrolisis epidermal toksik ditemukan pertama kali pada tahun 1956, sebanyak 4 kasus oleh Alana Lyell, penyakit ini biasanya juga disebut sindrom Lyell. NET ditemukan oleh Alana Lyell dengan gambaran berupa erupsi yang menyerupai luka bakar pada kulit akibat terkena cairan panas (scalding). Kondisi toksik mengacu pada beredarnya zat toksin dalam peredaran darah, dahulu kondisi ini dipikirkan sebagai penyebab dari nekrolisis epidermal toksik. Lyell menggunakan istilah 'nekrolisis' dengan menggabungkan gejala klinis epidermolisis dengan gambaran histopatologi 'nekrosis'. Beliau juga menggambarkan keterlibatan pada membran mukosa sebagai bagian dari sindrom, dan ditemukan hanya terjadi sedikit inflamasi di 
daerah dermis, sebuah tanda yang kemudian disebut 'dermal silence'. Penyebab NET belum jelas, tetapi obat-obatan (sulfonamid dan butazones) dan spesies Staphylococcus merupakan penyebab utama. Istilahistilah seperti 'staphylococcal-induced toxic epidermal necrolysis' dan 'drug-induced scalded skin syndrome' menang selama beberapa dekade, tetapi sekarang dipisahkan karena terapi dan prognosisnya berbeda. Oleh karena itu nekrolisis epidermal toksik atau NET merupakan penyakit erupsi kulit yang umumnya timbul akibat obat-obatan dengan lesi berupa bulla, dengan penampakan kulit seperti terbakar yang menyeluruh. ${ }^{9,10,11}$

\section{KASUS}

Seorang pasien laki-laki usia 30 tahun dirawat di bangsal Penyakit Dalam RSUP DR M Djamil Padang dengan keluhan utama kulit yang bertambah melepuh hampir di seluruh tubuh sejak 3 hari sebelum masuk rumah sakit. Awalnya, 7 minggu yang lalu pasien mengalami demam yang sudah dirasakan 3 hari sebelumnya. Pasien lalu berobat ke puskesmas dan diobati oleh mantri di Puskesmas tersebut. Pasien didiagnosis dengan malaria lalu diberikan dua suntikan pada bokong dan 5 macam obat tablet warna pink, putih, hijau, dan 2 lagi tidak teringat oleh pasien. Tiga hari kemudian, muncul bintik merah yang terasa gatal di dada, punggung, dan kedua lengan yang meluas hingga ke wajah. Pasien berobat kembali ke mantri yang sama, dan diberikan 4 macam obat untuk satu minggu yang tidak teringat oleh pasien warnanya dan 2 suntikan pada bokong. Selama satu minggu, pasien mengonsumsi obat tersebut namun tidak merasakan adanya pengurangan pada keluhan dan muncul bercak kemerahan yang semakin meluas pada dada, punggung, dan kedua lengan. Lalu, pasien berobat kembali ke mantri yang sama dan mendapatkan satu suntikan pada bokong dan 4 macam obat tablet yang tidak teringat oleh pasien warnanya. Karena tidak ada perbaikan selama satu minggu mengonsumsi obatobatan terakhir, pasien berobat ke praktik pribadi mantri yang lain. Dengan mantri tersebut, pasien diberikan satu suntikan pada bokong dan ketokonazol tablet, asam mefenamat, cefadroxil, dan metronidazol. Bintik merah dirasakan semakin banyak, bercak merah semakin meluas, dan muncul pembengkakan pada bibir dan ditutupi keropeng kehitaman. Satu minggu kemudian, pasien kembali ke mantri yang sama, mendapatkan satu suntikan di bokong dan empat obat tablet yang sama untuk satu minggu, begitu juga dengan satu minggu berikutnya.

Setelah menjalani pengobatan selama tiga minggu dengan mantri yang kedua, namun karena kulit tampak melepuh, bercak merah dirasakan semakin meluas dan gatal dirasakan semakin hebat, pasien kembali ke Puskesmas dan berobat dengan mantri yang pertama. Pasien diberikan satu suntikan di bokong dan mendapatkan CTM, Amoksisilin 500 mg, dan Paracetamol 500 mg. Namun, satu hari kemudian, pasien mengalami demam yang dirasakan terus menerus, namun tidak disertai menggigil dan tidak berkeringat banyak. Nanah berwarna kuning kehijauan timbul pada wajah, leher, dada, dan kedua lengan pasien. Pada mata tampak adanya nanah berwarna kuning kehijauan. Pasien dibawa ke RSUD dan langsung dipersiapkan untuk dirujuk ke RSUP Dr. M. Djamil Padang. Pada pemeriksaan fisik didapatkan tanda vital dalam batas normal, pada kulit didapatkan epidermolisis, krusta kehitaman, plak eritema, edema dan pus hampir di seluruh tubuh. Pada mata didapatkan skuama dan krusta pada palpebra, konjungtiva hiperemis, terdapat sekret kuning kehijauan.

Pada pemeriksaan laboratorium didapatkan hemoglobin $12,8 \mathrm{gr} / \mathrm{dl}$, hematokrit $38 \%$, leukosit $13.500 / \mathrm{mm}^{3}$, trombosit 291.000/. $\mathrm{mm}^{3}$, LED 115 $\mathrm{mm} / \mathrm{jam}$, hitung jenis 0/0/4/83/12/1, IgE Total $>10.000$ $\mathrm{IU} / \mathrm{ml}$.

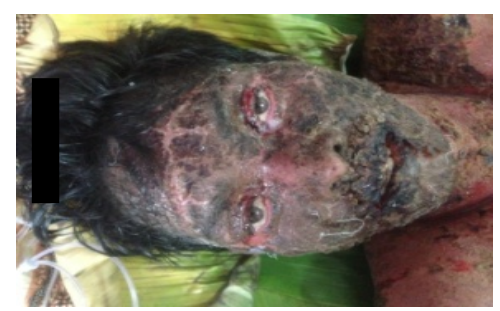

Gambar 1. Sebelum terapi

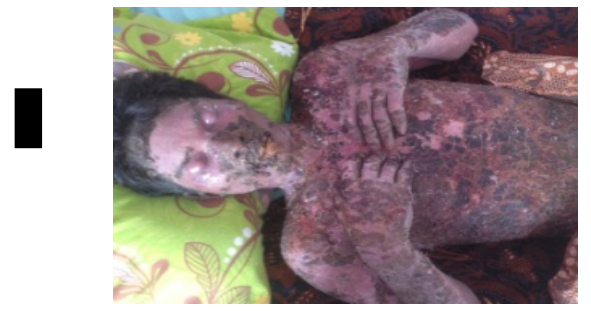

Gambar 2. Sebelum terapi 


\section{PEMBAHASAN}

Telah dirawat seorang pasien laki-laki usia 30 tahun di Bangsal Penyakit Dalam dengan diagnosis Hiper-lgE dengan Nekrolisis Epidermal Toksik (NET). Diagnosis pada pasien ini ditegakkan berdasarkan anamnesis, pemeriksaan fisik, dan pemeriksaan penunjang. Pasien datang dengan keluhan kulit yang bertambah melepuh sejak 3 hari sebelum masuk rumah sakit. Sebelumnya, pasien ini sudah mengonsumsi obat-obatan dari mantri selama 7 minggu berupa cefadroxil, metronidazol, ketokonazol, amoxicillin, asam mefenamat, paracetamol. Lalu, muncul bercak kemerahan pada kulit yang dirasakan semakin lama semakin luas yang disertai gatal. Kulit pun tampak melepuh. Adanya infeksi pada mukosa dan organ lain seperti mata, mengarahkan diagnosis ke Nekrolisis Epidermal, yang terdiri dari Sindrom Steven Johnson (SSJ) dan Nekrolisis Epidermal Toksik (NET). Penghitungan luas tubuh yang terkena lesi membedakan pasien ini menderita Sindrom Steven Johnson atau Nekrosis Epidermal Toksik. Kurang dari $10 \%$ berarti pasien menderita Sindrom Steven Johnson, lebih dari $30 \%$ berarti pasien menderita Nekrosis Epidermal Toksik, dan 10-30\% berarti overlapping SSJ dengan NET. Pasien ini mengalami lesi pada kulit lebih dari $30 \%$, sehingga ditegakkan NET. Terapi untuk NET ini adalah penghentian obat penyebab, perawatan suportif dan terapi spesifik. Perawatan suportif ditujukan untuk membatasi komplikasi. Kortikosteroid walaupun kontroversi, tetap menjadi terapi andalan.

Adanya lesi kulit yang luas yang disertai dengan infeksi, menimbulkan kecurigaan ke arah Sindrom Hiper-lgE. Oleh karena itu, pasien dilakukan pemeriksaan IgE total dengan hasil lebih dari 10.000 $\mathrm{IU} / \mathrm{ml}$. Diagnosis HIES berdasarkan pada kriteria Grimbacher dengan sistem skoring. Skoring pada pasien ini berjumlah 18. Berdasarkan kriteria, jika skor lebih dari 15 pasien didiagnosis dengan HIES. ${ }^{8}$ Pengobatan pada pasien ini adalah dengan perawatan kulit, cegah infeksi sekunder dan diberikan kortikosteroid yaitu injeksi Dexametason 6 x 5 mg.

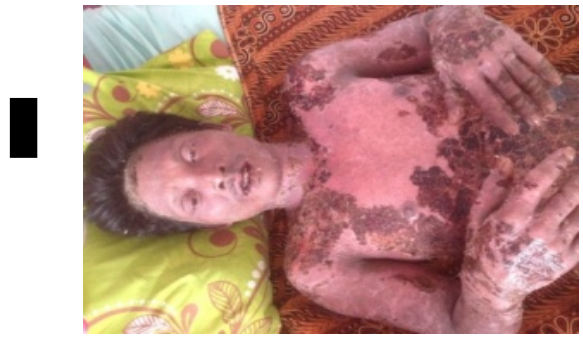

Gambar 3. Sesudah terapi

\section{SIMPULAN}

Hiper IgE dengan Nekrolisis Epidermal toksik merupakan kasus yang jarang. Pemberian terapi kortikosteroid dan perawatan kulit memberikan hasil yang baik pada pasien ini dengan teratasinya kelainan kulit dalam tujuh hari.

\section{DAFTAR PUSTAKA}

1. Woellner C, Schaffer A, Puck J. The Hyper-lgE syndrome and mutations in TYK2. Immunity. 2007; 26:535.

2. Minegishi Y, Saito M, Tsuchiya S. Dominantnegative mutations in the DNA-binding domain of STAT3 cause hyper-lgE syndrome. Nature. 2007;448:1058-62.

3. Holland SM, Deleo FR, Elloumi HZ. STAT3 mutation in the hyper IgEsyndrome. $\mathrm{N}$ Engl $\mathrm{J}$ Med. 2007;357:1608-19.

4. Scarabelli T. Amino acid supplementaton differentially modulates STAT1 and STAT3 actication in the myocardium exposed to ischemia/referfusion. Am J Cardiol. 2008;101:63E$8 \mathrm{E}$.

5. Freeman AF, Holland SM. The hyper IgE syndromes. Immunol Allergy Clin North Am. 2008;28(2):277-8.

6. Young TY, Jerome D, Gupta S. Hyperimmuneglobulinemia E Syndrome asociated with coronary artery aneurysms: deficiency of central memory CD4 T cell and expantion of effector memory CD4 T cells. Ann Allergy Asthma Immunol. 2007; 98: 389-92. 
7. Kim HJ, Kim JH, Shin YK, Lee SI, Ahn KM. A novel mutation in the linker domain of the signal tranducer and activator of transcrption 3 gene, p.Lys531Glu, in hyper-IgE syndrome. J Allergy Clin Immunol. 2009;123:956-8.

8. Grimbacher B, Scaffer AA, Holand SM, Davis J, Gallin JI, Malech HL, et al.. Genetic linkage of Hyper IgE syndrome to chromosome 4. Am J Hum Genet. 1999;65:735-44.

9. French EL, Prins C. Erythema Multiforme, StevensJohnson Syndrome and Toxic Epidermal Necrolysis. Dalam: Bolognia JL, Jorizzo JL, Rapini $\mathrm{RP}$, editor (penyunting). Dermatology. Edisi ke-2. London: Mosby; 2008.hlm.287-300.
10. Arnold HL, Odom RB, James WD. Contact dermatitis and drugs eruptions. Dalam: Arnold HL, Odom RB, James WD, editor (penyunting). Andrews' disease of the skin clinical dermatology. 10th ed. Philadelphia: WB Saunders Company; 2006.hlm.129-30.

11. Wolff K, Johnson RA. Severe and life-threatening skin eruptions in acutely III patient. Dalam: Wolff K, Johnson RA, editor (penyunting). Fitzpatrick's Color atlas and synopsis of clinical dermatology. Edisi ke-6. New York: Graw-Hill Companies; 2009. hlm.173-7. 